\title{
52nd Annual Meeting of the Society for Research into Hydrocephalus and Spina Bifida Hugh Richards
}

Address: Neurosurgery Unit, Box 167, Addenbrookes Hospital, Cambridge, CB2 0QQ, UK

Email: Hugh Richards - hkr10@medschl.cam.ac.uk

from 52nd Annual Meeting of the Society for Research into Hydrocephalus and Spina Bifida

Providence, RI, USA. II-14 June 2008

Published: 3 February 2009

Cerebrospinal Fluid Research 2009, 6(Suppl I):SI doi:I0.II86/I743-8454-6-SI-SI

This article is available from: http://www.cerebrospinalfluidresearch.com/content/6/SI/SI

(c) 2009 Richards; licensee BioMed Central Ltd.

The 52nd Annual Meeting of the Society for Research into Hydrocephalus and Spina Bifida was held at Brown University in Providence, Rhode Island at the invitation of Drs John Duncan, Conrad Johanson and Gerald Silverberg. The Society would like to thank the organizers, especially Conrad and his wife, Nancy, for making the meeting such a success.

Brown University was founded in 1764, one of the eight "Ivy League" Universities, and has an international reputation in teaching and research. The University lies on a hill overlooking the commercial centre of Providence and is a charming mix of $18^{\text {th }}$ and $19^{\text {th }}$ Century houses and a modern campus.

Following the Society's AGM, the social programme began with a welcome reception in the University's Faculty Club and continued on Thursday with a visit to "The Breakers", the Vanderbilt family's summer home in Newport, followed by a traditional "Clambake". The Conference dinner was held in the Federal Reserve in downtown Providence, a former bank.

The topics included in the scientific programme included sessions on Gene Expression - Basic Science, Early Hydrocephalus and Spina Bifida, Spina Bifida and Urology Development - Hydrocephalus and Spina Bifida, CSF Flow and Dynamics, Surgery and Infections, Normal Pressure Hydrocephalus and CSF Dynamics and Shunts. The Society was also pleased to welcome two distinguished invited speakers. The Casey Holter Memorial Lecture was given by Pro- fessor Andrew Copp from University College London entitled "Genetics and Embryology of Neural Tube Defects" and Professor Barbara Stonestreet from Brown University gave a lecture entitled "Intraventricular Hemorrhage in Premature Infants".

The meeting closed with an invitation from Stephen Brown, Alan Bailie and Nan Hill to the 53rd Annual Conference in Belfast, Northern Ireland on 24-27 June 2009.

The abstracts of all the presented papers are published in this supplement. It is the Society's policy to publish abstracts without editing. Any comments should be addressed directly to the authors. 